\title{
Can a Use-based Taxonomy be Natural? An example from Aguaruna folk classification of trees
}

\author{
Kevin Jernigan
}

\section{Research}

\begin{abstract}
This work examines the classic utilitarian vs. intellectualist debate in cognitive ethnobiology from a new perspective. It challenges the notion that classifications based on utility are artificial, that is, necessarily constructed from a few special characteristics. The paper involves a new analysis of ethnographic data collected by the author over multiple field sessions from 2004 to 2010 in nine Aguaruna villages in Amazonas, Peru. In previous work, Aguaruna participants described uses, along with sensory and ecological characteristics of local tree species. They also stated which tree folk genera they consider related to each other as "companions," typically placing taxa together in natural groupings. This new synthesis took the descriptions of uses and physical characteristics for a sample of 41 Aguaruna tree folk genera and subjected both to hierarchical cluster analysis to see which would better reproduce the folk classification. Use data performed nearly as well as sensory data in reproducing the natural groupings of trees. This makes sense considering that plant uses tend to be based on physical properties (including presence of secondary compounds) that related species will often share.
\end{abstract}

\section{Introduction}

\section{Bases for classification}

A classic and ongoing debate within the field of ethnobiology relates to the relative strengths of intellectualist, ecological, and utilitarian approaches to folk classification (Anderson 2000, 2010, Atran 1998, Berlin 1991, 1992, Hunn 1982, Posey 1984). Folk taxonomic systems typically give linguistic recognition to only a portion of the biological diversity in any given region (Berlin 1991, Hunn 1982). Some authors (Berlin 1991,1992) maintain that the most perceptually distinctive organisms have the greatest probability of being named. Others (Hunn 1982) have emphasized the importance of usefulness, arguing that cultural knowledge should be adaptive. Evidence (Berlin 1992, Posey 1984) suggests that ecological relationships also play an important role in classification.

Debate has focused not only on the factors motivating classification but also on the mechanics of how folk taxonomies are organized (Atran 1998, Berlin et al. 1974, Hunn 1982). An important aspect of these discussions concerns the naturalness of taxonomic schemes. Natural (or general purpose) schemes group together members based on many common shared characteristics (Berlin et al. 1966). Modern scientific classification is a good example. Conversely, artificial (or special) classification schemes use a small number of characteristics designed for a particular purpose. For instance, one might classify plants as "edible," "medicinal" or "psychoactive." Berlin $(1991,1992)$ argues that the widespread agreement between scientific and folk systems of classification provides good evidence

\section{Correspondence}

Kevin Jernigan, Anthropology Department, University of Alaska, Fairbanks, Alaska, U.S.A.

kjernigan@alaska.edu

Ethnobotany Research \& Applications 12:685-703 (2014)

Published: 22 December 2014

www.ethnobotanyjournal.org/vol12/i1547-3465-12-685.pdf 
that the latter are general purpose, based on observations of the morphological and behavioral qualities of organisms. Similarly, Atran maintains that folk taxonomies are general-purpose schemes that work "to maximize inductive potential relative to human interests" (1998:563). Hunn (1982) has suggested that folk classifications are based on an extensive natural core along with a periphery of artificial taxa based on utilitarian considerations. In any case, major contributors in this field (Berlin 1992, Ellen 2008, Hunn 1982) have largely discussed use-based classifications as being artificial rather than natural. The possibility that utility based classification schemes could be natural has largely not been explored. The present article examines this assumption through a detailed analysis of the Aguaruna life form category númi - "trees." Specifically, it tests the hypothesis: When sensory and ecological characters listed by Aguaruna participants for local trees are subjected to a hierarchical cluster analysis, the resulting classification will be a natural one. However, a similar analysis based on use characters should fail to produce natural groupings.

\section{Background}

\section{Study site}

This study involves a new analysis of ethnographic data collected over multiple field sessions of the author and collaborators in nine Aguaruna villages from 2004 to 2010. The previous studies interviewed 30 adult Aguaruna participants, focusing on the process of tree identification (Jernigan 2006b, 2008), medical ethnobotany (Jernigan 2009), and knowledge of life histories of local birds and mammals (Jernigan 2006a, 2010, Jernigan \& Dauphine 2008). The work involved researchers from the University of Georgia, the University of Alaska, Fairbanks, and the Universidad Nacional Mayor San Marcos in Lima, Peru.

All work took place on the upper Marañón river (see Figure 1), in the department of Amazonas, Peru, approximately $300 \mathrm{~km}$ northeast of the major Peruvian city of Chiclayo. This is an area of high species diversity of both flora and fauna (Jernigan \& Dauphine 2008). These studies all

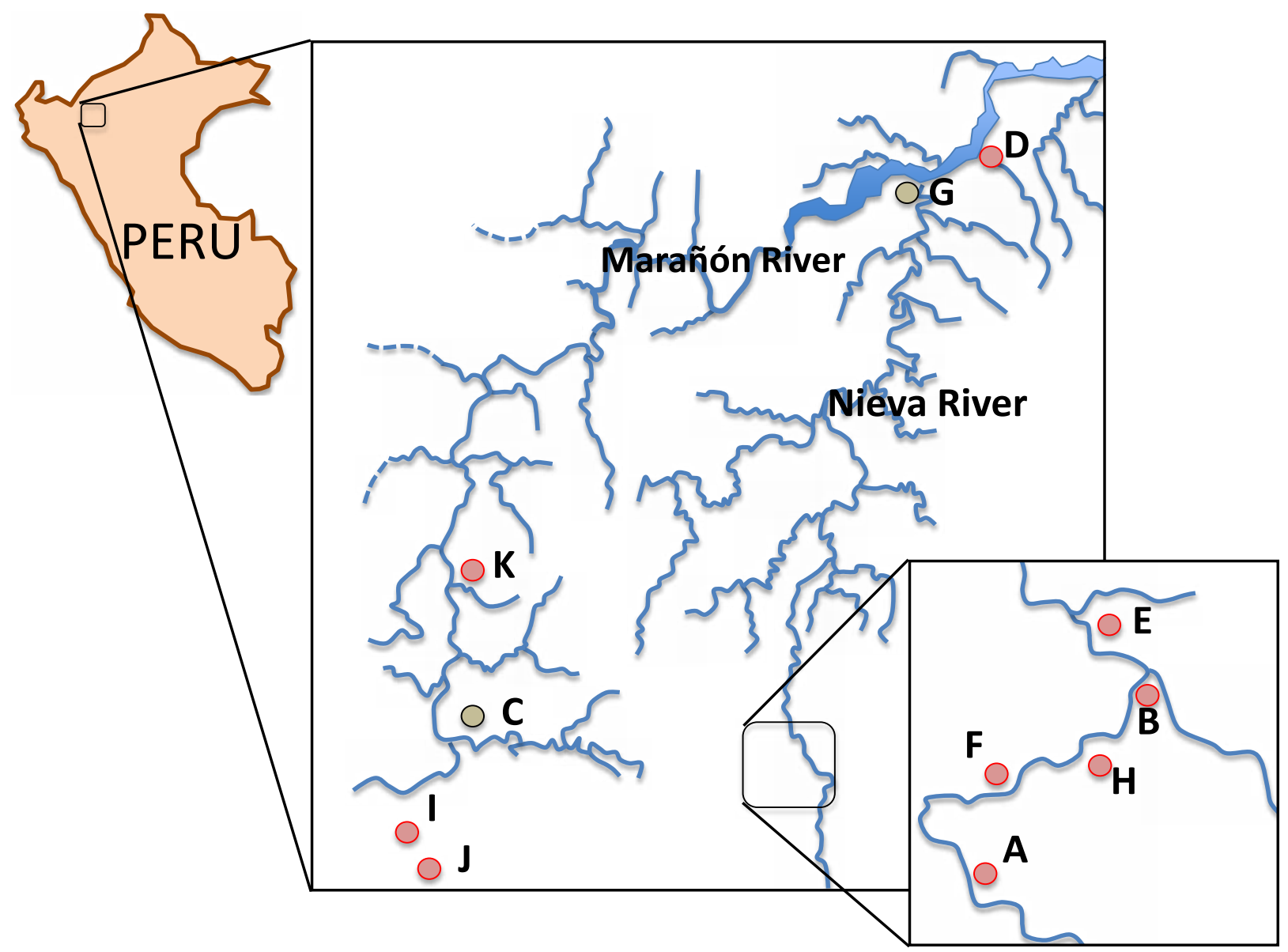

Figure 1. Study area on the upper Marañón river, Amazonas, Peru. Communities of A) Atash Shinukbau, B) Bajo Cachiaco, C) Chiriaco, D) Ciro Alegria, E) Kayamas, F) Pagki, G) Santa Maria de Nieva, H) Tunants, I) Wawas, J) Wichim, and $\mathbf{K}$ ) Yangunga. Red denotes study communities, grey denotes other communities. 


\section{Jernigan - Can a Use-based Taxonomy be Natural? An example from Aguaruna folk classification of trees}

conformed to American Anthropological Association ethical guidelines (1998-2012). For all work, prior informed consent was obtained first at the community level, then from individual participants. Permission was also granted by the Peruvian Ministry of Agriculture for collecting botanical voucher specimens.

Approximately 40,000 people in this region identify ethnically as Aguaruna (Lewis et al. 2013). Local traditional subsistence practices focus on swidden agriculture, supplemented by wild plant foods and meat from livestock, wild game, and fish. Despite some expansion of market economies in recent years, local substance activities continue to dominate (Jernigan 2006b).

The present analysis relies on interviews from the native communities of Alto Pagki, Atash Shinukbau, Bajo Cachiaco, Ciro Alegria, Kayamas, Tunants, Wawas, Wichim, and Yangunga (Figure 1). All research participants are Aguaruna speakers, and interviews were carried out by the author and collaborators in that language. Villages range in elevation from 300-600 masl, corresponding to a transition zone between lowland and montane tropical evergreen forest.

\section{Aguaruna folk taxonomy}

The present discussion of Aguaruna folk taxonomy focuses on the life form category númi, which includes most of what falls under the English folk category "tree." However, it excludes soft-wooded taxa such as Carica papaya L. (papái) and palms in general (Jernigan 2006b). For a wider treatment of Aguaruna folk classification see Berlin (1992) and Jernigan (2006b).

Aguaruna classification has a built-in mechanism for recognizing the relatedness of certain folk genera within a life form category. Such related taxa are called kumpaji
- "companions." In previous research (Jernigan 2006a), the author asked Aguaruna participants to group folk genera of trees that they consider to be companions. For example, the majority of participants recognized the relatedness of trees in the genus Cecropia (Urticaceae), including satík (Cecropia membranacea Trécul) and súu (Cecropia engleriana Snethl.). As with many of the companion groupings, this particular group can be justified in terms of both morphological similarities and similar uses. Both Cecropia species have palmate leaves with long petioles and clusters of oblong fruit. Both serve as firewood and have sap that treats hepatitis and anemia.

A majority of "companions" form natural groupings from the perspective of modern scientific taxonomy. However, occasionally trees that are not biologically closely related can also be considered kumpají. For example, the species shijíg (Hevea guianensis Aubl.), tákae (Brosimum parinarioides Ducke) and barát (Chrysophyllum sanguinolentum subsp. balata (Ducke) T.D. Penn.) are often placed together because they each have copious white sap that serves as a source of rubber.

\section{Methods}

In previous work (Jernigan 2006a, 2008, 2009, 2010), Aguaruna participants freelisted the following for local tree species: 1) their uses, 2) their physical characteristics (e.g. "the trunk is smooth" or "the sap is white") and 3) their ecological relationships with animals (e.g., "the fruit is eaten by tapirs" or "stinging ants live in the trunk").

The present analysis takes a sample of 41 Aguaruna tree folk genera of high salience in freelists that are widely agreed to form 15 distinct groups of related "companions" (Table 1) (Jernigan 2006a). Scientific names in this table are those accepted in the Tropicos database (Mis-

Table 1. Trees used for analysis of sensory, ecological, and use character hierachical clusters in Amazonas, Peru. Voucher numbers preceded by $\mathrm{J}$ indicate Kevin Jernigan collections, which are deposited in the Universidad Nacional Mayor de San Marcos, herbarium (USM). Other letters indicate collections deposited at Missouri Botanical Garden, herbarium (MO): $\mathrm{A}=$ Ernesto Ancuash, $\mathrm{H}=$ Victor Huashikat, $\mathrm{K}=$ Rubio Kayap.

\begin{tabular}{|l|l|r|}
\hline Grouping of Aguaruna taxa & Scientific taxa & Voucher \\
\hline GROUP 1 & APOCYNACEAE & \\
\hline úchi dáum & Couma macrocarpa Barb.Rodr. & J188 \\
\hline úchi táuch & Lacmellea oblongata Markgr. & J199 \\
\hline GROUP 2 & BURSERACEAE & \\
\hline wáwa kunchái & Dacryodes belemensis Cuatrec. & J58 \\
\hline újuts & Dacryodes uruts-kunchae Daly, M.C.Martínez \& D.A.Neill & J48 \\
\hline GROUP 3 & BURSERACEAE & \\
\hline shijíkap & Protium sp. & $\mathrm{J} 54$ \\
\hline chípa & Protium amazonicum (Cuatrec.) Daly & $\mathrm{J} 70$ \\
\hline pantuí & Protium grandifolium Engl. & $\mathrm{J} 49$ \\
\hline
\end{tabular}




\begin{tabular}{|c|c|c|}
\hline Grouping of Aguaruna taxa & Scientific taxa & Voucher \\
\hline shíshi & Protium spruceanum (Benth.) Engl. & A427 \\
\hline GROUP 4 & CLUSIACEAE & \\
\hline wayámpainim & Garcinia madruno (Kunth) Hammel & $\mathrm{J} 275$ \\
\hline pegkáenum & Garcinia macrophylla Mart. & J119 \\
\hline GROUP 5 & FABACEAE & \\
\hline putsúu sámpi & Inga sp. & J60 \\
\hline wámpa & Inga edulis Mart. & $\mathrm{J} 63$ \\
\hline buabúa & Inga cf. multinervis T.D.Penn. & J71 \\
\hline sejempách & Inga semialata (Vell.) C.Mart. & $\mathrm{J} 212$ \\
\hline GROUP 6 & FABACEAE & \\
\hline samíknum & Macrolobium acaciifolium (Benth.) Benth. & J82 \\
\hline wampíshkunim & Macrolobium limbatum Benth. & J56 \\
\hline GROUP 7 & FABACEAE & \\
\hline pandáij & Ormosia cf. amazonica Ducke & J114 \\
\hline tajép & Ormosia cf. coccinea (Aubl.) Jacks. & $\mathrm{J} 72$ \\
\hline GROUP 8 & FABACEAE & \\
\hline tigkíshpinim & Tachigali sp. & J261 \\
\hline ugkuyá & Tachigali formicarum Harms & $\mathrm{J} 264$ \\
\hline wantsún & Tachigali cf. bracteosa (Harms) Zarucchi \& Pipoly & $\mathrm{J} 270$ \\
\hline GROUP 9 & LAURACEAE & \\
\hline káwa tínchi & Nectandra olida Rohwer & $\mathrm{J} 268$ \\
\hline káikua & Licaria sp. & $\mathrm{J} 196$ \\
\hline wampúsnum & cf. Nectandra hihua (Ruiz \& Pav.) Rohw & $\mathrm{J} 53$ \\
\hline takák & Ocotea gracilis (Meisn.) Mez & $\mathrm{J} 272$ \\
\hline batút & Ocotea floribunda (Sw.) Mez & $\mathrm{H} 483$ \\
\hline káwa & Ocotea floribunda (Sw.) Mez & A170 \\
\hline GROUP 10 & LECYTHIDACEAE & \\
\hline kaáshnum & Eschweilera gigantea (R.Knuth) J.F.MacBr. & J102 \\
\hline shuwát & Eschweilera sp. & J217 \\
\hline GROUP 11 & MALVACEAE & \\
\hline wampúush & Ceiba pentandra (L.) Gaertn. & $\mathrm{J} 266$ \\
\hline ménte & not determined & J122 \\
\hline GROUP 12 & MELASTOMATACEAE & \\
\hline tseék & Miconia ternatifolia Triana & $\mathrm{J} 75$ \\
\hline ukuínmanch & Miconia lourteigiana Wurdack & J267 \\
\hline antumú chinchák & Miconia sp. & J216 \\
\hline chijáwe & Miconia bubalina (D.Don) Naudin & $\mathrm{J} 112$ \\
\hline GROUP 13 & MELIACEAE & \\
\hline yantsáu & Guarea guidonia (L.) Sleumer & $\mathrm{K} 60$ \\
\hline bíchauj & Guarea macrophylla ssp. pendulispica (C.DC.) T.D.Penn. & $\mathrm{J} 74$ \\
\hline GROUP 14 & MYRISTICACEAE & \\
\hline ejésh & Iryanthera tricornis Ducke & $\mathrm{J} 80$ \\
\hline úntuch tsémpu & Iryanthera juruensis Warb. & $\mathrm{J} 55$ \\
\hline
\end{tabular}




\section{Jernigan - Can a Use-based Taxonomy be Natural? An example from Aguaruna folk classification of trees}

\begin{tabular}{|l|l|r|}
\hline Grouping of Aguaruna taxa & Scientific taxa & Voucher \\
\hline GROUP 15 & URTICACEAE & \\
\hline satík & Cecropia membranacea Trécul & K805 \\
\hline súu & Cecropia engleriana Snethl. & J273 \\
\hline
\end{tabular}

souri Botanical Garden 2014), corresponding to the APG III system of classification. Members of these 15 groupings belong to the same biological genus in 12 cases and same family in the remaining three. The sample only includes companion groupings that are also natural from a modern biological perspective, since the aim of this research is to investigate what kinds of reasoning can form the basis for natural classification.

\section{Data analysis}

The sensory, ecological, and use characters for the 41 study trees were subjected to separate hierarchical cluster analyses to see which results would correspond best with participants' statements about how these trees are related as "companions." This classificatory method takes data in the form of vectors and produces increasingly inclusive groups based on some measure of the distance between them (Bernard 1995:505). Here, each vector corresponds to one of the 41 study trees, and each element in it represents a particular sensory, ecological, or use character. The value of each element is the proportion of participants who mentioned that particular character state (e.g. white sap, fruit eaten by oilbirds) for a given tree. The furthest neighbor clustering method was chosen for these analyses because it tends to produce small, tight groupings, avoiding the tendency toward chaining found with single linkage methods (Rokach \& Maimon 2005). Cosine distances were used because they take into account the similarity in overall pattern of the elements that make up the vectors (in this case the character states), without taking into account vector magnitudes (Diekhoff 1992).

The sensory, ecological, and utility characters used in the analyses can be found in Appendices 1-3. A total of 73 sensory characters (Appendix 1) includes 23 related to fruit, nine to the outer trunk appearance, eight for leaves, seven for cut bark, six for sap, five for growth habit, five for seeds, four for the inner trunk, four for flowers, one for roots, and one for branches.

Ecological characters (Appendix 2) include 65 categories of birds, 13 for mammals, and two for insects. To simplify the presentation of the data, the table headings are broad groupings such as "parrots" or "monkeys." Certainly many of these headings encompass multiple Aguaruna folk taxa. However, a complete listing would make for an overly extensive table, since some trees are said to be food for dozens of different animal species. The biological identity of Aguaruna bird names is based on research conducted by Boster et al. (1986), Jernigan (2006a), and
Jernigan and Dauphiné (2008). For mammal names, the work of Guallart (1962) and Berlin and Patton (1979) are referenced. Insect identifications are based on Guallart (1969).

Fifty-five use characters for the study trees are shown in Appendix 3. A full description of uses of all local woody flora is beyond the scope of this article, but see Jernigan (2006b) for a more detailed presentation. A few Aguaruna illness terms require further explanation, since the correspondence to biomedical categories is not always precise. Jágku is generally found in the elderly, and symptoms include pain and swelling of the joints (Brown 1984). It can be glossed as "rheumatism." The major symptom of shíip is bloody or mucousy diarrhea. It most likely corresponds to amebiasis. Yunchít is an illness whose primary symptoms are small mouth ulcers, irritation of the tongue, and hoarseness of the voice. It is sometimes associated with a bout of cold or flu and occurs most frequently in children (Brown 1984). Uwarai Yagkug et al. (1998) state that yunchít is equivalent to scurvy. The disease term úgku refers to a pus-filled boil and can be accompanied by a fever (Brown 1984). lyágbau (Figure 2) refers to swelling caused by dislocations or fractures.

\section{Results}

The dendrograms for the hierarchical cluster analyses of the sensory, ecological, and use characters appear in Figures 3-5 respectively.

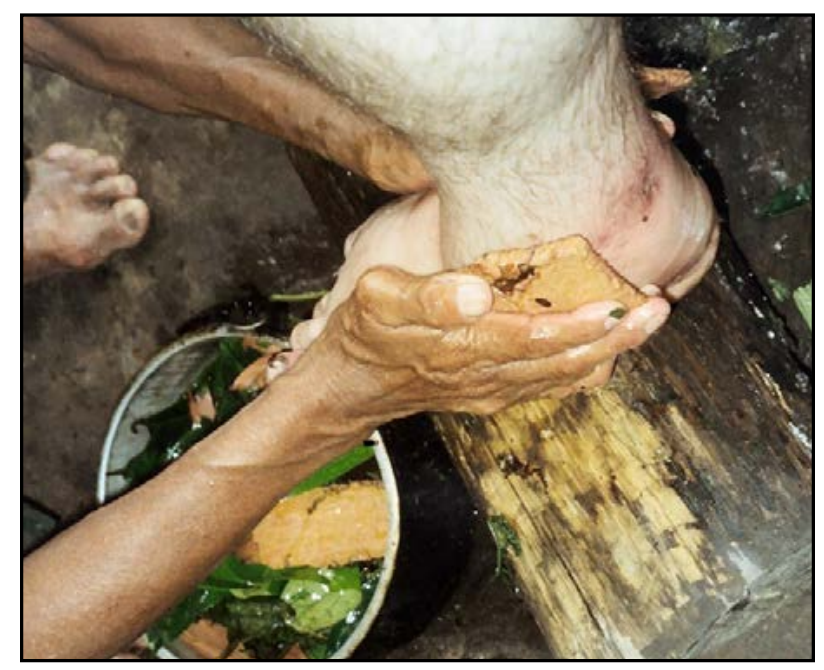

Figure 2. The author's swollen foot (iyágbau) being treated with hot pieces of tajép (Ormosia cf. coccinea (Aubl.) Jacks.), community of Bajo Cachiaco, Amazonas, Peru. 
Figure 3. Dendrogram for hierarchical clustering of sensory characters of 41 study trees in Amazonas, Peru. M. acaciifolium = Macrolobium acaciifolium (Benth.) Benth.; M. limbatum = Macrolobium limbatum Benth.; T. formicarum = Tachigali formicarum Harms.

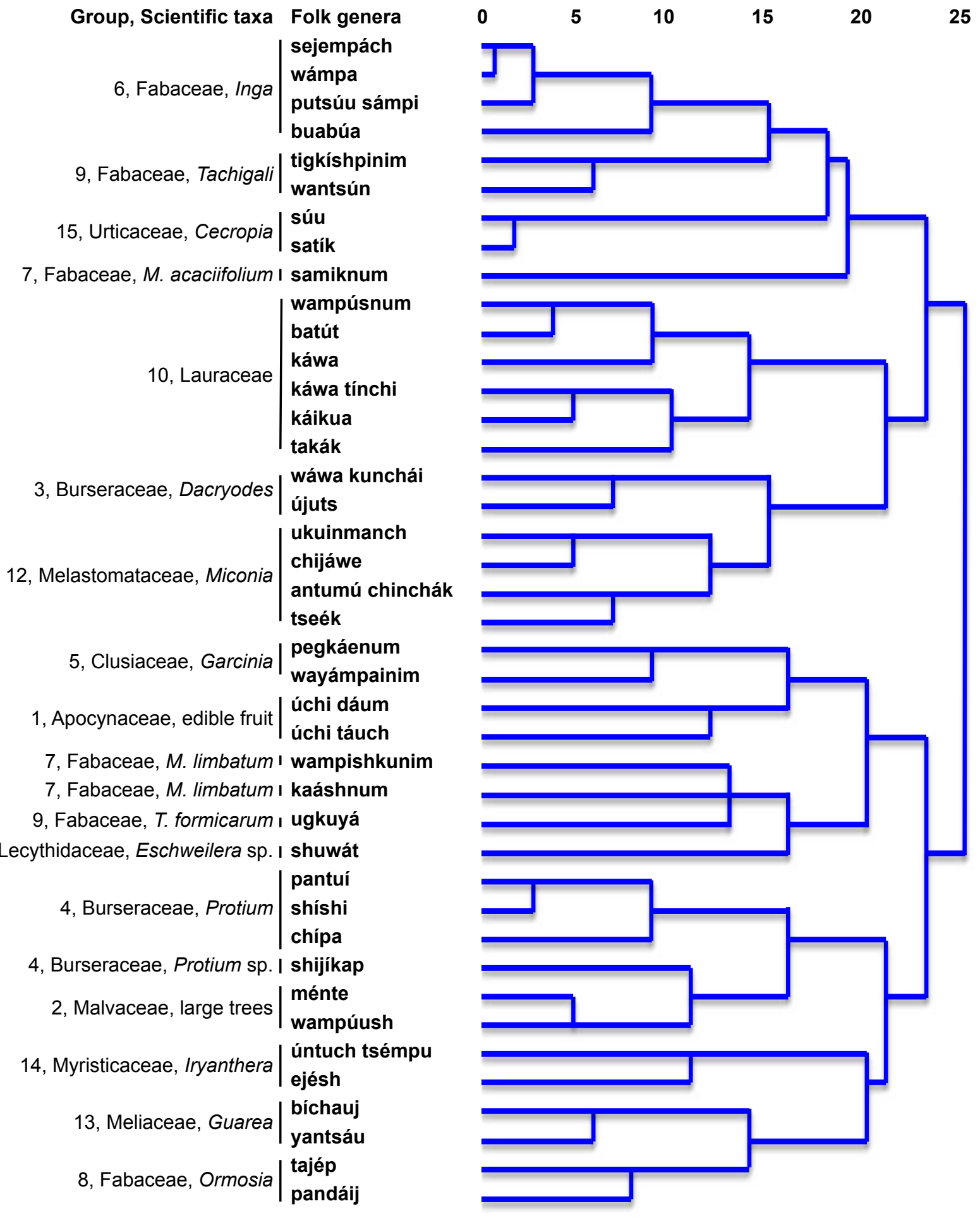




\section{Jernigan - Can a Use-based Taxonomy be Natural? An example from Aguaruna folk classification of trees}

Figure 4. Dendrogram for hierarchical clustering of ecological characters of the 41 study trees in Amazonas, Peru. C. macrocarpa $=$ Couma macrocarpa Barb.Rodr.; $D$. kukachkana = Dacryodes kukachkana L.O.Williams; D. urutskunchae = Dacryodes uruts-kunchae D.C. Daly \& M.C.Martinez; G. macrophylla = Garcinia macrophylla Mart.; G. madruno = Garcinia madruno (Kunth) Hammel; L. oblongata = Lacmellea oblongata Markgr.; N. hihua = Nectandra hihua (Ruiz \& Pav.) Rohwer; P. spruceanum = Protium spruceanum (Benth.) Engl.

\section{Group, Scientific taxa Folk genera \\ 9, Fabaceae, Tachigali $\mid \begin{aligned} & \text { ugkuyá } \\ & \text { tigkishpinim }\end{aligned}$ \\ wantsún}

12, Melastomataceae, Miconia antumú chinchák tseék chijáwe ukuínmanch

1, Apocynaceae, L. oblongata I úchi táuch

5 , Clusiaceae, G. madruno I wayámpainim 1, Apocynaceae, C. macrocarpa , úchi dáum

5, Clusiaceae, G. macrophylla ı pegkáenum

$$
\text { 8, Fabaceae, Ormosia }\left.\right|_{\text {pandáij }} ^{\text {tajép }}
$$

7, Fabaceae, Macrolobium | wampíshkunim

4, Burseraceae, Protium |chípa pantuí

3 , Burseraceae, $D$. uruts-kunchae I újuts

10, Lauraceae, Licaria sp. I káikua

3, Burseraceae, D. kukachkana I wáwa kunchái

14, Myristicaceae, Iryanthera úntuch tsémpu ejésh

10, Lauraceae $\begin{aligned} & \text { káwa tínchi } \\ & \text { batút } \\ & \text { takák } \\ & \text { káwa }\end{aligned}$

4, Burseraceae, P. spruceanum I shíshi

13, Meliaceae, Guarea bíchauj yantsáu

15, Urticaceae, Cecropia $\begin{aligned} & \text { súu } \\ & \text { satík }\end{aligned}$

10, Lauraceae, cf. N. hihua , wampúsnum

4, Burseraceae, Protium sp. I shijíkap

11, Lecythidaceae, Eschweilera kaáshnum shuwát

2, Malvaceae, large trees ménte wampúush putsúu sámpi wámpa

6, Fabaceae, Inga sejempách buabúa

\section{Rescaled Distance Cluster Combine}
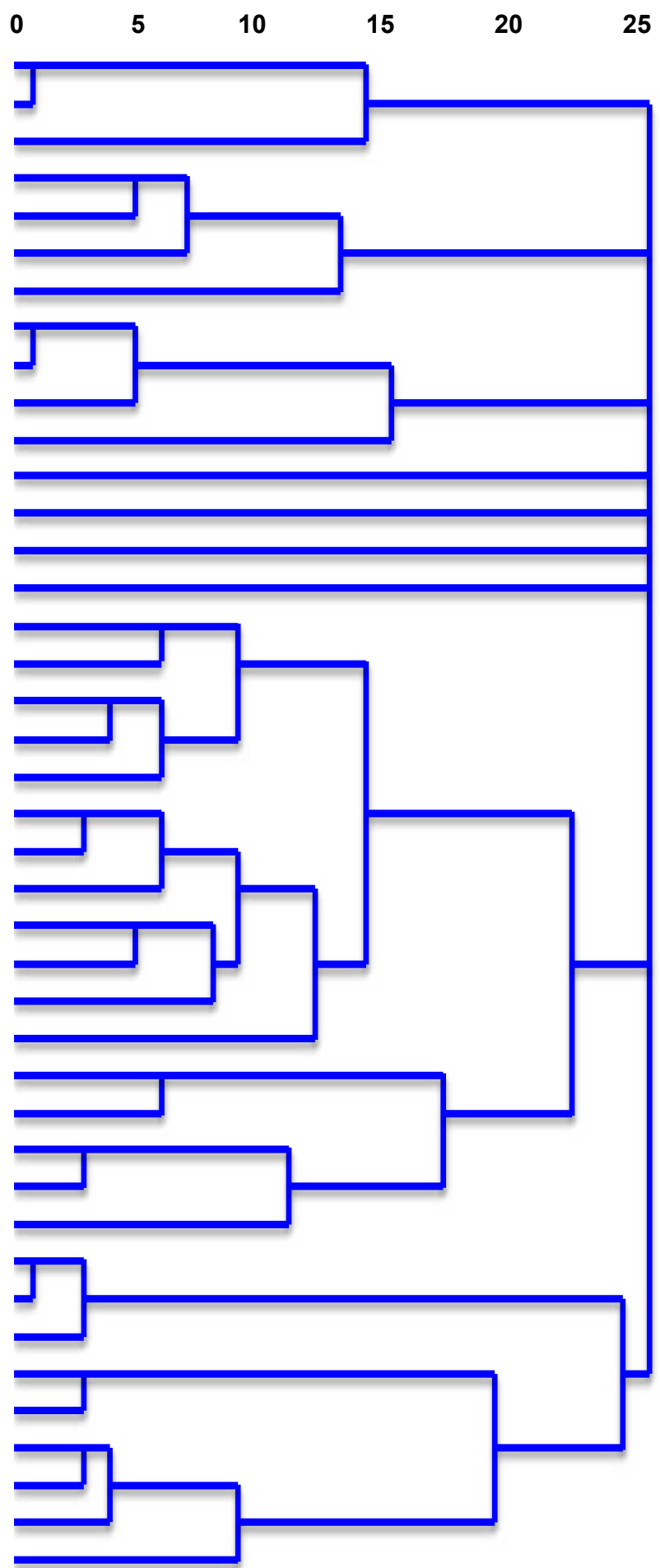
Figure 5. Dendrogram for hierarchical clustering of use characters of the 41 study trees in Amazonas, Peru. G. macrophylla = Garcinia macrophylla Mart.; G. madruno = Garcinia madruno (Kunth) Hammel; N. hihua = Nectandra hihua (Ruiz \& Pav.) Rohwer; O. cf. floribunda = Ocotea cf. floribunda (Sw.) Mez

\section{Group, Scientific taxa Folk genera \\ 6, Fabaceae, Inga $\begin{aligned} & \text { putsúu sámpi } \\ & \text { buabúa }\end{aligned}$}

5, Clusiaceae, G. macrophylla | pegkáenum

3, Burseraceae, Dacryodes $\mid \begin{aligned} & \text { wáwa kunchái } \\ & \text { újuts }\end{aligned}$

5, Clusiaceae, G. madruno | wayámpainim

6, Fabaceae, Inga $\begin{aligned} & \begin{array}{l}\text { sejempách } \\ \text { wámpa }\end{array} \\ & \text { úchiáum }\end{aligned}$

1, Apocynaceae, edible fruit $\mid \begin{aligned} & \text { úchi dáum } \\ & \text { úchi táuch }\end{aligned}$

2, Malvaceae, large trees

14, Myristicaceae, Iryanthera

13, Meliaceae, Guarea

12, Melastomataceae, Miconia

11, Lecythidaceae, Eschweilera

10, Lauraceae $\begin{aligned} & \text { káwa tínchi } \\ & \text { káikua } \\ & \text { káwa } \\ & \text { takák }\end{aligned}$

12, Melastomataceae, Miconia

ukuínmanch

chijáwe

9, Fabaceae, Tachigali

$\mid \begin{aligned} & \text { tigkíshpinim } \\ & \text { wantsún } \\ & \text { ugkuyá }\end{aligned}$

10, Lauraceae, O. cf. floribunda I batút
8, Fabaceae, Ormosia
$\mid \begin{aligned} & \text { tajép } \\ & \text { pandáij }\end{aligned}$

15, Urticaceae, Cecropia

7, Fabaceae, Macrolobium

4, Burseraceae, Protium

súu

satík

wampíshkunim

samíknum

10, Lauraceae, cf. N. hihua | wampúsnum

4, Burseraceae, Protium $\mid \begin{aligned} & \text { shíshi } \\ & \text { shijíkap }\end{aligned}$

\section{Rescaled Distance Cluster Combine}
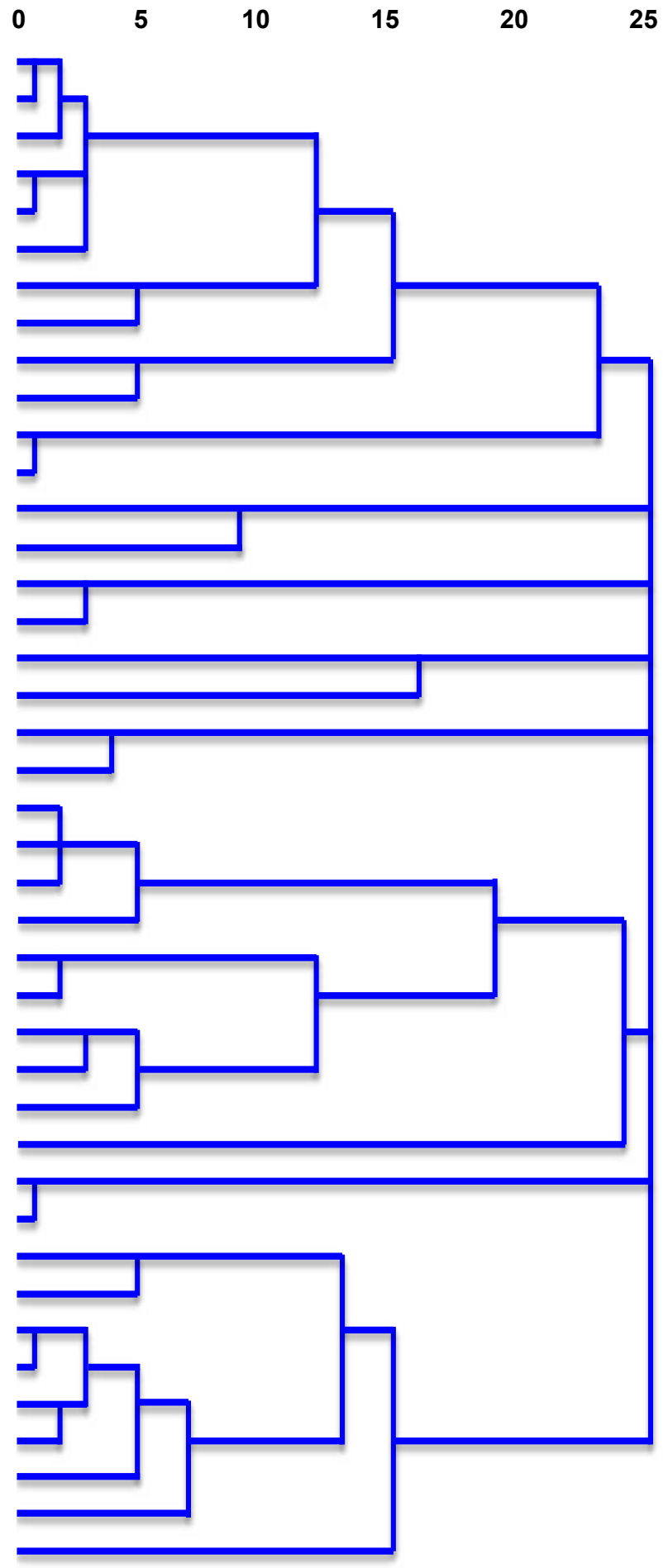


\section{Jernigan - Can a Use-based Taxonomy be Natural? An example from Aguaruna folk classification of trees}

\section{Discussion}

\section{Hierarchical clustering results}

Sensory characters fully reproduced 11 of 15 (73\%) of the original "companion" groups in the folk classification, while use characters reproduced ten (67\%). The ecological analysis fared a bit worse, fully reconstructing only seven groupings (47\%). One explanation for this last result is that participants did not mention any animal species associated with a few trees from the genera Macrolobium and Ormosia in the Fabaceae.

Reasons vary why certain "companion" groups were fully or partially unresolved under these analyses. For example, when ecological characters are considered, the Melastomataceae (group 12) hold together. Their fruit are all eaten by similar species of small birds such as tanagers and manakins. However, when usefulness is taken into account, the companions separate. Instead, there is a smaller grouping of the trees ukuínmanch (Miconia lourteigiana Wurdack) and chijáwe (Miconia bubalina Naudin), which have hard heartwood and serve as upright posts for house construction. The other members of this family lack those characters and cluster apart. To give another example, the Lauraceae (group 9) hold together based on the sensory analysis. They all possess a very characteristic aromatic odor in their leaves and bark. However, some Lauraceae fall off when looking at ecological characters. Since wampúsnum (cf. Nectandra hihua (Ruiz \& Pav.) Rohwer) is found along the banks of rivers, participants said riverine birds such as icterids and tyrant flycatchers feed on its fruit. However, most Lauraceae are found on higher ground and therefore are associated with different birds. Only companion group 2 (genus Protium, Burseraceae) failed to resolve in any of the hierarchical clusters.

Twelve of the companion groups consist of trees in the same genus, while the remaining three are made up of trees in the same botanical family. One might expect to see a positive correlation between the taxonomic closeness of members of the companion groups and how well they were resolved under the hierarchical clustering. However, this does not appear to be the case. The three groups related only to the level of family $(1,9$, and 11) are reproduced by an average of 2 out of the three clustering methods. The remaining groups representing a single biological genus are reproduced by an average of 1.9 out of the three methods. So taxonomic distance cannot explain any differences in how the companion groups are resolved.

\section{Conclusions}

Both use and sensory characters show similari potential in reproducing Aguaruna folk classification of trees. So the original hypothesis of this research is not supported. The ability of use characters to reproduce a natural classification can be explained by noting that plant uses are often based on physical properties. These include some that are not readily observable at first glance that may provide information that could be helpful in making a natural classification. For example, Aguaruna use of the trees yantsáu (Guarea guidonia (L.) Sleumer) and bíchauj (Guarea macrophylla ssp. pendulispica (C.DC.) T.D.Penn.) in the Meliaceae to treat shíip - "watery diarrhea," relying on the presence of secondary chemicals with antibiotic properties (Simoni et al. 1996). The use of resin from Protium species (Burseraceae) to make torches for illumination relies on the presence of flammable monoterpenes (Siani et al. 1999). Other uses of trees might reflect physical properties influencing durability and flammability of wood or the palatability and nutrition of fruit.

None of the character types were able to perfectly reproduce the folk classification. In the present hierarchical clustering analysis, all character states were given equal weight. However, academic taxonomists have found that not all characters are equally useful at a given level of taxonomic hierarchy (Stuessy 1990:33). Some characters tend to be more conservative over evolution than others. For example, within the mostly temperate genus Quercus (oaks), the character leaf shape is quite variable (see Brown \& Kirkman 1990), but leaf arrangement is not, since all oaks have alternate leaves. Leaf shape, therefore, would be a useful feature for distinguishing between oak species, while leaf arrangement may be useful for distinguishing the genus Quercus from other genera. In fact, previously published evidence (Jernigan 2006a) hints that the Aguaruna may place greater emphasis on certain characters and less on others when deciding which tree folk genera are related as companions. When a small group of participants were asked to explicitly justify why they considered certain trees to be companions, the types of morphological characters they mentioned the most were: fruit color, sap color, fruit dehiscence, and bark odor. Future research would expand this line of questioning with regard to sensory, ecological, and use characters for the trees in question to test whether that would yield a hierarchical clustering result that is even closer to the Aguaruna folk classification.

\section{Acknowledgments}

The author received generous support for this research from the National Science Foundation (nos. 0314289 and 0754434) and the Wenner-Gren Foundation for Anthropological Research. I would also like to thank Brent Berlin, Elois Ann Berlin, and Glenn Shepard for many helpful discussions and much encouragement over the years. Various people in the herbarium of the Universidad Nacional Mayor de San Marcos, in Lima, kindly helped me identify botanical specimens. These included Joaquina Albán, Hamilton Beltrán, Severo Baldeón, Franco Mellado, Mirbel Epiquien, and Irayda Salinas. Most of all, I would 
like to thank the people of the communities of Alto Pagki, Atash Shinukbau, Bajo Cachiaco, Ciro Alegria, Kayamas, Tunants, Wawas, Wichim, and Yangunga. In particular, Tercero Lirio, Martín Reategui, Nestor Reategui, and Gregorio Reategui were very helpful in their assistance with coordinating this research. Finally, I thank the Peruvian Ministry of Agriculture for granting authorization for collecting botanical voucher specimens.

\section{Literature Cited}

Anderson, E.N. 2000. Maya knowledge and "science wars." Journal of Ethnobiology 20:129-158.

Anderson, E.N. 2010. Yucatec Maya botany and the "nature" of science. Journal of Ecological Anthropology 14(1):67-73.

Atran, S. 1998. Folkbiology and the anthropology of science: Cognitive universals and cultural particulars. Behavioral Brain Sciences 21(4):547-609.

Berlin, B. 1970. A Preliminary Ethnobotanical Survey of the Aguaruna Region of the Upper Marañón River Valley, Amazonas, Peru. Report to the Wenner-Gren Foundation for Anthropological Research, Washington, D.C., U.S.A.

Berlin, B. 1991. The chicken and the egghead revisited: Further evidence for the intellectualist bases of ethnobiological classification. Pp. 57-66 in Man and a Half: Essays in Pacific anthropology and ethnobiology in honour of Ralph Bulmer. Edited by A. Pawley. The Polynesian Society, Auckland, New Zealand.

Berlin, B. 1992. Ethnobiological Classification: Principles of categorization of plants and animals in traditional societies. Princeton University Press, Princeton, New Jersey, U.S.A.

Berlin, B., J.S. Boster \& J.P. O'Neil. 1981. The perceptual basis of ethnobiological classification: Evidence from Aguaruna Jívaro ornithology. Journal of Ethnobiology 1:95-108. http://ethnobiology.org/sites/default/files/pdfs/ JoE/1-1/Berlin et al1981.pdf

Berlin, B., D.E. Breedlove \& P.H. Raven. 1966. Folk taxonomies and biological classification. Science 154:273275. 154(3746):273-275. dx.doi.org/10.1126/science. 154.3746 .273

Berlin, B., D.E. Breedlove \& P.H. Raven. 1974. Principles of Tzeltal Plant Classification. Academic Press, New York, New York, U.S.A.

Berlin, B. \& J.L. Patton. 1979. La Clasificación de los Mamíferos de los Aguaruna, Amazonas, Perú. Language Behavior Research Laboratory, Berkeley, California, U.S.A.
Bernard, H.R. 1995. Research Methods in Anthropology: Qualitative and quantitative approaches. Altamira Press, Walnut Creek, California, U.S.A.

Boster, J.S., B. Berlin \& J.P. O'Neill. 1986. The correspondence of Jivaroan to scientific ornithology. American Anthropologist 88(3):569-583. dx.doi.org/10.1525/ aa.1986.88.3.02a00020

Brown C.L. \& L.K. Kirkman. 1990. Trees of Georgia and Adjacent States. Timber Press, Portland, Oregon, U.S.A.

Brown, M.F. 1984. Una Paz Incierta: Comunidades Aguarunas frente al impacto de la carretera marginal. Centro Amazónico de Antropología y Aplicación Práctica, Lima, Peru.

Diekhoff, G. 1992. Statistics for the Social and Behavioral Sciences: Univariate, bivariate, multivariate. William C. Brown Publishers, Dubuque, lowa, U.S.A.

Ellen, R.F. 2008. Ethnomycology among the Nuaulu of the Moluccas: Putting Berlin's 'general principles' of ethnobiological classification to the test. Economic Botany 62(3):483-496. dx.doi.org/10.1007/s12231-008-9036-5

Guallart, J.M. 1962. Nomenclatura Jíbara-Aguaruna de especies de mamíferos en el alto Marañón. Biota 4(32):155-164.

Guallart, J.M. 1969. Nomenclatura Jíbara-Aguaruna de especies de aves en el Alto Marañón. Mesa Redonda de Ciencias Prehistóricas y Antropólogas 1:150-160.

Hunn, E.S. 1982. The utilitarian factor in folk biological classification. American Anthropologist 84(4):830-847. dx.doi.org/10.1525/aa.1982.84.4.02a00070

Jernigan, K. 2006a. An ethnobotanical investigation of tree identification by the Aguaruna Jivaro of the Peruvian Amazon. Journal of Ethnobiology 26(1):107-125. dx.doi. org/10.2993/0278-0771(2006)26[107:AEIOTI]2.0.CO;2

Jernigan, K. 2006b. An Ethnobiological Exploration of Sensory and Ecological Aspects of Tree Identification Among the Aguaruna Jivaro. Ph.D. dissertation. University of Georgia, Athens, Georgia, U.S.A.

Jernigan, K. 2008. The importance of chemosensory clues in Aguaruna tree classification and identification. Journal of Ethnobiology and Ethnomedicine 4:12. dx.doi. org/10.1186/1746-4269-4-12

Jernigan, K. 2010. Behind the scenes: Human conflict disrupts bird research in Amazon. LiveScience www.livescience.com/animals/peru-amazon-birds-bts-100702. $\underline{\mathrm{html}}$ 


\section{Jernigan - Can a Use-based Taxonomy be Natural? An example from Aguaruna folk classification of trees}

Jernigan, K. \& N. Dauphine. 2008. Aguaruna knowledge of bird foraging ecology: A comparison with scientific data. Ethnobotany Research and Applications 8:99-106. http:// journals.sfu.ca/era/index.php/era/article/view/195

Missouri Botanical Garden. 2014. Tropicos Database. www.tropicos.org

Posey, D. 1984. Hierarchy and utility in a folk biological taxonomic system: Patterns in the classification of arthropods by the Kayapo Indians of Brazil. Journal of Ethnobiology 4:123-139. http://ethnobiology.org/sites/default/ files/pdfs/JoE/4-2/Posey1984.pdf

Rokach, L. \& O. Maimon. 2005. Clustering methods. Pp. 321-352 in The Data Mining and Knowledge Discovery Handbook. Edited by O. Maimon \& L. Rokach. Springer, New York, New York, U.S.A.
Siani, A.C. \& M.D.S. Ramos. 1999. Evaluation of anti-inflammatory-related activity of essential oils from the leaves and resin of species of Protium. Journal of Ethnopharmacology 66(1):57-69. dx.doi.org/10.1016/S03788741(98)00148-2

Simoni I.C., V. Munford, J.D. Felicio \& A.P. Lins. 1996. Antiviral activity of crude extracts of Guarea guidonia. Revista Brasileira de Pesquisas Médicas e Biológicas 29(5):647-50.

Stuessy, T. 1990. Plant Taxonomy: The systematic evaluation of comparative data. Columbia University Press, New York, New York, U.S.A.

Uwarai Yagkug, A., I. Paz Suikai \& J. Regan. 1998. Diccionario Aguaruna Castellano: Awajún Chichám Apáchnaujai. Centro Amazónico de Antropología y Práctica, Lima, Peru. 
Appendix 1. Sensory characters of 41 study trees in Amazonas, Peru. Voucher evidence cited in Table 1.

\begin{tabular}{|c|c|c|}
\hline $\begin{array}{l}\text { Grouping of } \\
\text { Aguaruna taxa }\end{array}$ & Scientific taxa & Most salient sensory characters \\
\hline GROUP 1 & APOCYNACEAE & \\
\hline úchi dáum & Couma macrocarpa Barb.Rodr. & $\begin{array}{l}\text { Tall tree; trunk dark colored, rough; copious, sticky white } \\
\text { sap; leaves rounded; fruits large, yellow and round; } \\
\text { reddish flowers. }\end{array}$ \\
\hline úchi táuch & Lacmellea oblongata Markgr. & $\begin{array}{l}\text { Short tree; trunk parted; copious, sticky, white sap; small, } \\
\text { narrow leaves; clusters of round yellow sweet fruits; black } \\
\text { seeds; white flowers. }\end{array}$ \\
\hline GROUP 2 & BURSERACEAE & \\
\hline wáwa kunchái & Dacryodes belemensis Cuatrec. & $\begin{array}{l}\text { A tall, thick tree; bark has aromatic odor; fruits oblong, } \\
\text { black; flowers red. }\end{array}$ \\
\hline újuts & $\begin{array}{l}\text { Dacryodes uruts-kunchae Daly, } \\
\text { M.C.Martínez \& D.A.Neill }\end{array}$ & $\begin{array}{l}\text { A small tree; trunk is grey; bark has aromatic odor; sap } \\
\text { forms balls on the trunk; leaves small and rounded; fruits } \\
\text { small, oblong, black. }\end{array}$ \\
\hline GROUP 3 & BURSERACEAE & \\
\hline shijíkap & Protium sp. & $\begin{array}{l}\text { A tall, thick tree with stilt roots; bark has aromatic odor; } \\
\text { white sap forms balls on the trunk; leaves small; fruit } \\
\text { round, dehiscent and white inside. }\end{array}$ \\
\hline chípa & Protium amazonicum (Cuatrec.) Daly & $\begin{array}{l}\text { A tall, straight tree; trunk is grey; bark has aromatic odor; } \\
\text { leaves are long; the yellowish fruits are in clusters, break } \\
\text { open, white inside. }\end{array}$ \\
\hline pantuí & Protium grandifolium Engl. & $\begin{array}{l}\text { A tall tree with stilt roots; bark has aromatic odor; leaves } \\
\text { long, narrow and rounded; fruit round, breaks open, white } \\
\text { inside. }\end{array}$ \\
\hline shíshi & Protium spruceanum (Benth.) Engl. & $\begin{array}{l}\text { Tree with stilt roots; trunk is grey; bark has aromatic odor; } \\
\text { sap is white, sticky; leaves small, rounded; clusters of } \\
\text { small round fruit that are dehiscent, white inside. }\end{array}$ \\
\hline GROUP 4 & CLUSIACEAE & \\
\hline wayámpainim & Garcinia madruno (Kunth) Hammel & $\begin{array}{l}\text { A tall, straight tree; trunk is dark; sap is yellow; leaves } \\
\text { small and rounded; fruit large, round, yellow. }\end{array}$ \\
\hline pegkáenum & Garcinia macrophylla Mart. & $\begin{array}{l}\text { A tall, thick tree, with dark trunk; sap is sticky and yellow; } \\
\text { leaves long and narrow; fruit large, round, yellow; flowers } \\
\text { reddish. }\end{array}$ \\
\hline GROUP 5 & FABACEAE & \\
\hline putsúu sámpi & Inga sp. & $\begin{array}{l}\text { A tall, straight tree; leaves small, narrow; fruit long, white } \\
\text { and sweet inside; flowers white. }\end{array}$ \\
\hline wámpa & Inga edulis Mart. & $\begin{array}{l}\text { A medium sized tree; trunk is grey; leaves narrow, } \\
\text { rounded, light when young; fruit is big, long, white and } \\
\text { sweet inside; flowers white. }\end{array}$ \\
\hline buabúa & Inga cf. multinervis T.D.Penn. & $\begin{array}{l}\text { Short, thick tree; trunk grey; leaves long and wide; the } \\
\text { long, wide, fruit is white and sweet inside; the seeds are } \\
\text { large; flowers are white. }\end{array}$ \\
\hline sejempách & Inga semialata (Vell.) C.Mart. & $\begin{array}{l}\text { A medium sized tree; leaves are small, narrow, rounded; } \\
\text { fruit long, white and sweet inside; flowers white. }\end{array}$ \\
\hline GROUP 6 & FABACEAE & \\
\hline samíknum & $\begin{array}{l}\text { Macrolobium acaciifolium } \\
\text { (Benth.) Benth. }\end{array}$ & $\begin{array}{l}\text { A tall, straight tree; trunk grey and smooth; wood hard, } \\
\text { heavy; leaves small; fruit is oblong flat and dehiscent; } \\
\text { flowers white. }\end{array}$ \\
\hline
\end{tabular}




\section{Jernigan - Can a Use-based Taxonomy be Natural? An example from Aguaruna folk classification of trees}

\begin{tabular}{|c|c|c|}
\hline $\begin{array}{l}\text { Grouping of } \\
\text { Aguaruna taxa }\end{array}$ & Scientific taxa & Most salient sensory characters \\
\hline wampíshkunim & Macrolobium limbatum Benth. & $\begin{array}{l}\text { A tall, straight tree; wood hard; leaves long, rounded; fruit } \\
\text { is oblong, flat, dark and dehiscent; flowers white. }\end{array}$ \\
\hline GROUP 7 & FABACEAE & \\
\hline pandáij & Ormosia cf. amazonica Ducke & $\begin{array}{l}\text { A tall, thick, straight tree with buttressed roots; leaves } \\
\text { oblong and slightly reddish on reverse; fruit in clusters, } \\
\text { long, flat, brownish on outside and dehiscent; seeds red } \\
\text { and black. }\end{array}$ \\
\hline tajép & Ormosia cf. coccinea (Aubl.) Jacks. & $\begin{array}{l}\text { A thick tree; trunk grey; leaves oblong and slightly reddish } \\
\text { on reverse; fruit in clusters, long, brownish on outside and } \\
\text { dehiscent; seeds red; flowers reddish. }\end{array}$ \\
\hline GROUP 8 & FABACEAE & \\
\hline tigkíshpinim & Tachigali sp. & $\begin{array}{l}\text { A thick, straight tree with buttressed roots; trunk yellowish } \\
\text { and parted; leaves narrow and slightly yellowish; fruit } \\
\text { long, flat, light colored and dehiscent; flowers whitish. }\end{array}$ \\
\hline ugkuyá & Tachigali formicarum Harms & $\begin{array}{l}\text { A tall, straight tree; trunk parted; leaves narrow; fruit long } \\
\text { and light colored. }\end{array}$ \\
\hline wantsún & $\begin{array}{l}\text { Tachigali cf. bracteosa } \\
\text { (Harms) Zarucchi \& Pipoly }\end{array}$ & $\begin{array}{l}\text { A tall, thick, straight tree with buttressed roots; leaves } \\
\text { narrow and slightly yellowish; fruit long, flat, light colored } \\
\text { and dehiscent. }\end{array}$ \\
\hline GROUP 9 & LAURACEAE & \\
\hline káwa tínchi & Nectandra olida Rohwer & $\begin{array}{l}\text { A tall, thick tree; bark has aromatic odor; wood yellowish } \\
\text { inside; leaves small and rounded; fruit black when mature, } \\
\text { with aromatic odor. }\end{array}$ \\
\hline káikua & Licaria sp. & $\begin{array}{l}\text { A tall tree; bark has aromatic odor and peels off; leaves } \\
\text { small and narrow; fruit oblong, black when mature, with } \\
\text { aromatic odor; flowers white. }\end{array}$ \\
\hline wampúsnum & $\begin{array}{l}\text { cf. Nectandra hihua } \\
\text { (Ruiz \& Pav.) Rohw }\end{array}$ & $\begin{array}{l}\text { A short, thick tree with buttressed roots; trunk dark; bark } \\
\text { has aromatic odor; leaves long; fruit small and black } \\
\text { when mature, oblong, with aromatic odor; flowers white. }\end{array}$ \\
\hline takák & Ocotea gracilis (Meisn.) Mez & $\begin{array}{l}\text { A tall, straight tree with buttressed roots; trunk grey; bark } \\
\text { has aromatic odor; wood yellowish inside; leaves long, } \\
\text { narrow and slightly yellowish; oblong fruit is large, black } \\
\text { when mature, with aromatic odor; flowers white. }\end{array}$ \\
\hline batút & Ocotea floribunda (Sw.) Mez & $\begin{array}{l}\text { A tall tree; trunk dark; bark has aromatic odor; leaves } \\
\text { small and rounded; the round fruit is black when mature, } \\
\text { has an aromatic odor; flowers white. }\end{array}$ \\
\hline káwa & Ocotea floribunda (Sw.) Mez & $\begin{array}{l}\text { A tall, thick, straight tree with buttressed roots; trunk } \\
\text { dark and parted; bark has aromatic odor; wood yellowish } \\
\text { inside; leaves small; fruit small, oblong and black when } \\
\text { mature, with an aromatic odor; flowers white. }\end{array}$ \\
\hline GROUP 10 & LECYTHIDACEAE & \\
\hline kaáshnum & $\begin{array}{l}\text { Eschweilera gigantea } \\
\text { (R.Knuth) J.F.MacBr. }\end{array}$ & $\begin{array}{l}\text { A tall tree; trunk dark; bark rough; wood is hard; leaves } \\
\text { narrow; fruit rounded, oblong, with operculate lid; flowers } \\
\text { reddish white. }\end{array}$ \\
\hline shuwát & Eschweilera sp. & $\begin{array}{l}\text { A tall, thick tree with buttressed roots; bark rough; leaves } \\
\text { narrow and rounded; fruit large, rounded and dehiscent; } \\
\text { seeds wind dispersed; flowers reddish white. }\end{array}$ \\
\hline
\end{tabular}




\begin{tabular}{|c|c|c|}
\hline $\begin{array}{l}\text { Grouping of } \\
\text { Aguaruna taxa }\end{array}$ & Scientific taxa & Most salient sensory characters \\
\hline GROUP 11 & MALVACEAE & \\
\hline wampúush & Ceiba pentandra (L.) Gaertn. & $\begin{array}{l}\text { A tall, thick tree with buttressed roots; thorny trunk, } \\
\text { especially when young; leaves small and clustered; the } \\
\text { large oblong fruit are dark on the outside, dehiscent with } \\
\text { white cotton inside; seeds black; flower white. }\end{array}$ \\
\hline ménte & not determined & $\begin{array}{l}\text { A tall, thick tree with buttressed roots; thorny trunk, } \\
\text { especially when young; leaves small and clustered; the } \\
\text { large oblong fruit are yellowish on the outside, dehiscent } \\
\text { and white inside; flower white or red. }\end{array}$ \\
\hline GROUP 12 & MELASTOMATACEAE & \\
\hline tseék & Miconia ternatifolia Triana & $\begin{array}{l}\text { A small tree; trunk grey; leaves long, narrow and rounded; } \\
\text { has clusters of small, black fruit; flowers white. }\end{array}$ \\
\hline ukuínmanch & Miconia lourteigiana Wurdack & $\begin{array}{l}\text { A small, straight tree; trunk grey and parted; wood is hard; } \\
\text { leaves narrow, reddish on the back; has clusters of small, } \\
\text { black fruit. }\end{array}$ \\
\hline $\begin{array}{l}\text { antumú } \\
\text { chinchák }\end{array}$ & Miconia sp. & $\begin{array}{l}\text { A small tree; leaves rounded and reddish on the back; } \\
\text { clusters of black fruit; flowers white. }\end{array}$ \\
\hline chijáwe & Miconia bubalina (D.Don) Naudin & $\begin{array}{l}\text { A small, straight tree; trunk parted; wood is hard; leaves } \\
\text { narrow, rounded and reddish on the back; clusters of } \\
\text { small black, round fruit; flowers white. }\end{array}$ \\
\hline GROUP 13 & MELIACEAE & \\
\hline yantsáu & Guarea guidonia (L.) Sleumer & $\begin{array}{l}\text { A thick tree with buttressed roots; trunk parted; bark } \\
\text { has aromatic odor; leaves narrow and long; clusters of } \\
\text { oblong, red, dehiscent fruits that are white inside; seeds } \\
\text { red; flowers white. }\end{array}$ \\
\hline bíchauj & $\begin{array}{l}\text { Guarea macrophylla ssp. } \\
\text { pendulispica (C.DC.) T.D.Penn. }\end{array}$ & $\begin{array}{l}\text { A short tree; trunk dark; bark has aromatic odor; clusters } \\
\text { of oblong, red, dehiscent fruits; seeds red; flowers white. }\end{array}$ \\
\hline GROUP 14 & MYRISTICACEAE & \\
\hline ejésh & Iryanthera tricornis Ducke & $\begin{array}{l}\text { A tall, thick, straight tree; trunk parted; sap light, reddish; } \\
\text { leaves narrow; fruit oblong, dehiscent and red inside. }\end{array}$ \\
\hline úntuch tsémpu & Iryanthera juruensis Warb. & $\begin{array}{l}\text { A tall, thick, straight tree; trunk rough; sap sticky and red; } \\
\text { leaves long and narrow; fruit oblong, dehiscent, red inside } \\
\text { and cauliflorous. }\end{array}$ \\
\hline GROUP 15 & URTICACEAE & \\
\hline satík & Cecropia membranacea Trécul & $\begin{array}{l}\text { Has stilt roots; trunk grey; leaves wide, palmate, with long } \\
\text { petiole; clusters of long, yellowish fruit. }\end{array}$ \\
\hline súu & Cecropia engleriana Snethl. & $\begin{array}{l}\text { A tall tree with stilt roots; trunk grey; leaves wide, palmate } \\
\text { with long, thick petiole; clusters of long, yellowish fruit. }\end{array}$ \\
\hline
\end{tabular}




\section{Jernigan - Can a Use-based Taxonomy be Natural? An example from Aguaruna folk classification of trees}

Appendix 2. Ecological characters of 41 study trees in Amazonas, Peru. Voucher evidence cited in Table 1.

\begin{tabular}{|c|c|c|}
\hline $\begin{array}{l}\text { Grouping of } \\
\text { Aguaruna taxa }\end{array}$ & Scientific taxa & Aminal associations \\
\hline GROUP 1 & APOCYNACEAE & \\
\hline úchi dáum & Couma macrocarpa Barb.Rodr. & monkeys, rodents, peccaries, deer, tapirs, kinkajou \\
\hline úchi táuch & Lacmellea oblongata Markgr. & monkeys, rodents, peccaries, deer, kinkajou \\
\hline GROUP 2 & BURSERACEAE & \\
\hline wáwa kunchái & Dacryodes belemensis Cuatrec. & $\begin{array}{l}\text { toucans, cotingas, oilbird, parrots, tinamous, cracids, } \\
\text { peccaries, tapirs, rodents, bears, deer }\end{array}$ \\
\hline újuts & $\begin{array}{l}\text { Dacryodes uruts-kunchae Daly, } \\
\text { M.C.Martínez \& D.A.Neill }\end{array}$ & $\begin{array}{l}\text { toucans, cotingas, oilbird, parrots, tinamous, cracids, } \\
\text { peccaries, tapirs, rodents, bears }\end{array}$ \\
\hline GROUP 3 & BURSERACEAE & \\
\hline shijíkap & Protium sp. & parrots, rodents \\
\hline chípa & Protium amazonicum (Cuatrec.) Daly & $\begin{array}{l}\text { toucans, cotingas, parrots, tinamous, doves, barbets, } \\
\text { peccaries, rodents }\end{array}$ \\
\hline pantuí & Protium grandifolium Engl. & $\begin{array}{l}\text { toucans, cotingas, parrots, cracids, doves, thrushes, } \\
\text { barbets, icterids peccaries, rodents }\end{array}$ \\
\hline shíshi & Protium spruceanum (Benth.) Engl. & toucans, oilbird, tinamous, rodents \\
\hline GROUP 4 & CLUSIACEAE & \\
\hline wayámpainim & Garcinia madruno (Kunth) Hammel & monkeys, kinkajou, deer \\
\hline pegkáenum & Garcinia macrophylla Mart. & $\begin{array}{l}\text { parrots, tanagers, thrushes, barbets, manakins, icterids, } \\
\text { rodents, monkeys, kinkajou }\end{array}$ \\
\hline GROUP 5 & FABACEAE & \\
\hline putsúu sámpi & Inga sp. & $\begin{array}{l}\text { toucans, parrots, tinamous, cracids, doves, icterids, deer, } \\
\text { peccaries, rodents, monkeys, kinkajou }\end{array}$ \\
\hline wámpa & Inga edulis Mart. & $\begin{array}{l}\text { toucans, parrots, tanagers, icterids, peccaries, rodents, } \\
\text { monkeys, kinkajou }\end{array}$ \\
\hline buabúa & Inga cf. multinervis T.D.Penn. & $\begin{array}{l}\text { parrots, tinamous, peccaries, rodents, monkeys, kinkajou, } \\
\text { deer }\end{array}$ \\
\hline sejempách & Inga semialata (Vell.) C.Mart. & $\begin{array}{l}\text { toucans, parrots, tinamous, cracids, doves, icterids, } \\
\text { peccaries, rodents, monkeys, kinkajou, deer }\end{array}$ \\
\hline GROUP 6 & FABACEAE & \\
\hline samíknum & $\begin{array}{l}\text { Macrolobium acaciifolium } \\
\text { (Benth.) Benth. }\end{array}$ & none \\
\hline wampíshkunim & Macrolobium limbatum Benth. & none \\
\hline GROUP 7 & FABACEAE & \\
\hline pandáij & Ormosia cf. amazonica Ducke & none \\
\hline tajép & Ormosia cf. coccinea (Aubl.) Jacks. & tinamous \\
\hline GROUP 8 & FABACEAE & \\
\hline tigkíshpinim & Tachigali sp. & ants \\
\hline ugkuyá & Tachigali formicarum Harms & ants \\
\hline wantsún & $\begin{array}{l}\text { Tachigali cf. bracteosa } \\
\text { (Harms) Zarucchi \& Pipoly }\end{array}$ & ants, chiachia (unidentified insect sp.) \\
\hline GROUP 9 & LAURACEAE & \\
\hline káwa tínchi & Nectandra olida Rohwer & $\begin{array}{l}\text { cotingas, oilbird, parrots, tinamous, cracids, doves, } \\
\text { manakins, barbets, icterids, peccaries, rodents }\end{array}$ \\
\hline
\end{tabular}




\begin{tabular}{|c|c|c|}
\hline $\begin{array}{l}\text { Grouping of } \\
\text { Aguaruna taxa }\end{array}$ & Scientific taxa & Aminal associations \\
\hline káikua & Licaria sp. & $\begin{array}{l}\text { cotingas, oilbird, parrots, tinamous, cracids, doves, } \\
\text { barbets, thrushes, peccaries, rodents, deer }\end{array}$ \\
\hline wampúsnum & $\begin{array}{l}\text { cf. Nectandra hihua } \\
\text { (Ruiz \& Pav.) Rohw }\end{array}$ & $\begin{array}{l}\text { cotingas, oilbird, tinamous, cracids, doves, tanagers, } \\
\text { saltators, tyrant flycatchers, thrushes, barbets, icterids }\end{array}$ \\
\hline takák & Ocotea gracilis (Meisn.) Mez & $\begin{array}{l}\text { cotingas, oilbird, tinamous, cracids, peccaries, rodents, } \\
\text { ants }\end{array}$ \\
\hline batút & Ocotea floribunda (Sw.) Mez & $\begin{array}{l}\text { cotingas, oilbird, parrots, tinamous, cracids, doves, } \\
\text { peccaries, rodents, bears, deer }\end{array}$ \\
\hline káwa & Ocotea floribunda (Sw.) Mez & $\begin{array}{l}\text { cotingas, oilbird, parrots, tinamous, cracids, doves, } \\
\text { peccaries, rodents, deer }\end{array}$ \\
\hline GROUP 10 & LECYTHIDACEAE & \\
\hline kaáshnum & $\begin{array}{l}\text { Eschweilera gigantea } \\
\text { (R.Knuth) J.F.MacBr. }\end{array}$ & parrots, rodents, deer \\
\hline shuwát & Eschweilera sp. & parrots, tapirs, rodents, deer \\
\hline GROUP 11 & MALVACEAE & \\
\hline wampúush & Ceiba pentandra (L.) Gaertn. & parrots \\
\hline ménte & not determined & parrots, tinamous \\
\hline GROUP 12 & MELASTOMATACEAE & \\
\hline tseék & Miconia ternatifolia Triana & $\begin{array}{l}\text { toucans, cotingas, tinamous, cracids, tanagers, saltators, } \\
\text { tyrant flycatchers, thrushes, manakins, barbets, icterids }\end{array}$ \\
\hline ukuínmanch & Miconia lourteigiana Wurdack & doves, tanagers, manakins, monkeys \\
\hline $\begin{array}{l}\text { antumú } \\
\text { chinchák }\end{array}$ & Miconia sp. & $\begin{array}{l}\text { toucans, cotingas, parrots, tinamous, cracids, tanagers, } \\
\text { saltators, tyrant flycatchers, thrushes, manakins, barbets, } \\
\text { icterids }\end{array}$ \\
\hline chijáwe & Miconia bubalina (D.Don) Naudin & $\begin{array}{l}\text { toucans, cotingas, cracids, tanagers, thrushes, manakins, } \\
\text { barbets, icterids }\end{array}$ \\
\hline GROUP 13 & MELIACEAE & \\
\hline yantsáu & Guarea guidonia (L.) Sleumer & $\begin{array}{l}\text { toucans, tinamous, cracids, tanagers, saltators, tyrant } \\
\text { flycatchers, thrushes, manakins, barbets, icterids }\end{array}$ \\
\hline bíchauj & $\begin{array}{l}\text { Guarea macrophylla ssp. } \\
\text { pendulispica (C.DC.) T.D.Penn. }\end{array}$ & $\begin{array}{l}\text { toucans, parrots, tinamous, cracids, tanagers, saltators, } \\
\text { tyrant flycatchers, thrushes, barbets, icterids, rodents }\end{array}$ \\
\hline GROUP 14 & MYRISTICACEAE & \\
\hline ejésh & Iryanthera tricornis Ducke & $\begin{array}{l}\text { toucans, cotingas, oilbird, tinamous, barbets, peccaries, } \\
\text { tapirs, rodents, deer }\end{array}$ \\
\hline úntuch tsémpu & Iryanthera juruensis Warb. & $\begin{array}{l}\text { toucans, cotingas, parrots, tinamous, cracids, peccaries, } \\
\text { rodents, deer }\end{array}$ \\
\hline GROUP 15 & URTICACEAE & \\
\hline satík & Cecropia membranacea Trécul & $\begin{array}{l}\text { toucans, parrots, tanagers, tyrant flycatchers, barbets, } \\
\text { icterids, kinkajou, monkeys, ants }\end{array}$ \\
\hline súu & Cecropia engleriana Snethl. & $\begin{array}{l}\text { toucans, parrots, tanagers, tyrant flycatchers, thrushes, } \\
\text { barbets, icterids, kinkajou, ants }\end{array}$ \\
\hline
\end{tabular}




\section{Jernigan - Can a Use-based Taxonomy be Natural? An example from Aguaruna folk classification of trees}

Appendix 3. Use characters of 41 study trees in Amazonas, Peru. Voucher evidence cited in Table 1.

\begin{tabular}{|c|c|c|}
\hline $\begin{array}{l}\text { Grouping of } \\
\text { Aguaruna taxa }\end{array}$ & Scientific taxa & Uses \\
\hline GROUP 1 & APOCYNACEAE & \\
\hline úchi dáum & Couma macrocarpa Barb.Rodr. & $\begin{array}{l}\text { Fruit and sap edible; sap used as pitch for waterproofing } \\
\text { baskets, caulking canoes, firewood, treating the illnesses } \\
\text { shíip, diarrhea, dysentery and hepatitis as well as for } \\
\text { making rubber and decorating pottery }\end{array}$ \\
\hline úchi táuch & Lacmellea oblongata Markgr. & $\begin{array}{l}\text { Fruit edible; sap used as pitch for caulking canoes } \\
\text { treating the illness shíip and decorating pottery; wood } \\
\text { serves for firewood. }\end{array}$ \\
\hline GROUP 2 & BURSERACEAE & \\
\hline wáwa kunchái & Dacryodes belemensis Cuatrec. & Fruit edible; sap burned for illumination. \\
\hline újuts & $\begin{array}{l}\text { Dacryodes uruts-kunchae Daly, } \\
\text { M.C.Martínez \& D.A.Neill }\end{array}$ & Fruit edible; sap burned for illumination. \\
\hline GROUP 3 & BURSERACEAE & \\
\hline shijíkap & Protium sp. & $\begin{array}{l}\text { Wood used for firewood and to treat scorpion and stingray } \\
\text { stings; sap burned for illumination and for making tattoos }\end{array}$ \\
\hline chípa & Protium amazonicum (Cuatrec.) Daly & $\begin{array}{l}\text { Wood used in house construction, firewood, sap used for } \\
\text { decorating pottery. }\end{array}$ \\
\hline pantuí & Protium grandifolium Engl. & $\begin{array}{l}\text { Wood used in house construction, firewood, sap burned } \\
\text { for illumination. }\end{array}$ \\
\hline shíshi & Protium spruceanum (Benth.) Engl. & $\begin{array}{l}\text { Wood used in house construction, firewood, necklaces } \\
\text { (seeds), sap burned for illumination. }\end{array}$ \\
\hline GROUP 4 & CLUSIACEAE & \\
\hline wayámpainim & Garcinia madruno (Kunth) Hammel & Fruit edible; sap used for decorating pottery. \\
\hline pegkáenum & Garcinia macrophylla Mart. & Fruit edible; sap used to treat sores. \\
\hline GROUP 5 & FABACEAE & \\
\hline putsúu sámpi & Inga sp. & Fruit edible; wood used for firewood. \\
\hline wámpa & Inga edulis Mart. & $\begin{array}{l}\text { Fruit edible; wood used for firewood; sap used to trea } \\
\text { stomach aches and flu. }\end{array}$ \\
\hline buabúa & Inga cf. multinervis T.D.Penn. & Fruit edible; wood used for firewood. \\
\hline sejempách & Inga semialata (Vell.) C.Mart. & Fruit edible; wood used for firewood. \\
\hline GROUP 6 & FABACEAE & \\
\hline samíknum & $\begin{array}{l}\text { Macrolobium acaciifolium } \\
\text { (Benth.) Benth. }\end{array}$ & $\begin{array}{l}\text { Wood used for house construction, firewood; bark used to } \\
\text { help babies learn to walk. }\end{array}$ \\
\hline wampíshkunim & Macrolobium limbatum Benth. & Wood used for house construction and for firewood. \\
\hline GROUP 7 & FABACEAE & \\
\hline pandáij & Ormosia cf. amazonica Ducke & $\begin{array}{l}\text { Bark used to treat illnesses: iyágbau, jágku, and úgku } \\
\text { seeds used to make necklaces. }\end{array}$ \\
\hline tajép & Ormosia cf. coccinea (Aubl.) Jacks. & $\begin{array}{l}\text { Bark used to treat illnesses: iyágbau, jágku, and úgku } \\
\text { seeds used to make necklaces. }\end{array}$ \\
\hline GROUP 8 & FABACEAE & \\
\hline tigkíshpinim & Tachigali sp. & Wood used in construction of canoes and houses. \\
\hline ugkuyá & Tachigali formicarum Harms & $\begin{array}{l}\text { Wood used in construction of houses and also used to } \\
\text { treat impotence. }\end{array}$ \\
\hline
\end{tabular}




\begin{tabular}{|c|c|c|}
\hline $\begin{array}{l}\text { Grouping of } \\
\text { Aguaruna taxa }\end{array}$ & Scientific taxa & Uses \\
\hline wantsún & $\begin{array}{l}\text { Tachigali cf. bracteosa } \\
\text { (Harms) Zarucchi \& Pipoly }\end{array}$ & Wood used in construction of canoes and houses. \\
\hline GROUP 9 & LAURACEAE & \\
\hline káwa tínchi & Nectandra olida Rohwer & $\begin{array}{l}\text { Wood cut for lumber, making canoes and used in house } \\
\text { construction. }\end{array}$ \\
\hline káikua & Licaria sp. & $\begin{array}{l}\text { Wood cut for lumber, making canoes, seats and in house } \\
\text { construction. }\end{array}$ \\
\hline wampúsnum & $\begin{array}{l}\text { cf. Nectandra hihua } \\
\text { (Ruiz \& Pav.) Rohw }\end{array}$ & Wood used in house construction and for firewood. \\
\hline takák & Ocotea gracilis (Meisn.) Mez & $\begin{array}{l}\text { Wood cut for lumber, making canoes and in house } \\
\text { construction. }\end{array}$ \\
\hline batút & Ocotea floribunda (Sw.) Mez & $\begin{array}{l}\text { Wood used in house construction; the fruit is used to treat } \\
\text { jágku and anemia and also as perfume and as a charm } \\
\text { against illness. }\end{array}$ \\
\hline káwa & Ocotea floribunda (Sw.) Mez & $\begin{array}{l}\text { Wood cut for lumber, making canoes and in house } \\
\text { construction. }\end{array}$ \\
\hline GROUP 10 & LECYTHIDACEAE & \\
\hline kaáshnum & $\begin{array}{l}\text { Eschweilera gigantea } \\
\text { (R.Knuth) J.F.MacBr. }\end{array}$ & $\begin{array}{l}\text { The bark is used to make basket handles; wood used for } \\
\text { firewood. }\end{array}$ \\
\hline shuwát & Eschweilera sp. & $\begin{array}{l}\text { The wood is used to make doors and is cut for lumber; the } \\
\text { bark is used to make basket handles. }\end{array}$ \\
\hline GROUP 11 & MALVACEAE & \\
\hline wampúush & Ceiba pentandra (L.) Gaertn. & $\begin{array}{l}\text { Wood used for lumber; cotton used for dart fletching; } \\
\text { seeds used in necklaces and to help children hunt birds } \\
\text { better. }\end{array}$ \\
\hline ménte & not determined & $\begin{array}{l}\text { Wood used for lumber; cotton used for dart fletching; } \\
\text { seeds used to help children hunt birds better. }\end{array}$ \\
\hline GROUP 12 & MELASTOMATACEAE & \\
\hline tseék & Miconia ternatifolia Triana & $\begin{array}{l}\text { The wood is used to make beds; the fibrous bark serves } \\
\text { to make dog leashes; leaves used to dye clothing and } \\
\text { paint ceramics. }\end{array}$ \\
\hline ukuínmanch & Miconia lourteigiana Wurdack & The wood is used for house construction. \\
\hline $\begin{array}{l}\text { antumú } \\
\text { chinchák }\end{array}$ & Miconia sp. & The wood is used to make beds. \\
\hline chijáwe & Miconia bubalina (D.Don) Naudin & The wood is used for house construction. \\
\hline GROUP 13 & MELIACEAE & \\
\hline yantsáu & Guarea guidonia (L.) Sleumer & $\begin{array}{l}\text { The wood is used to make canoes, in house construction } \\
\text { and for lumber; the bark treats shíip. }\end{array}$ \\
\hline bíchauj & $\begin{array}{l}\text { Guarea macrophylla ssp. } \\
\text { pendulispica (C.DC.) T.D.Penn. }\end{array}$ & The bark treats shíip. \\
\hline GROUP 14 & MYRISTICACEAE & \\
\hline ejésh & Iryanthera tricornis Ducke & The sap is used to treat skin sores. \\
\hline úntuch tsémpu & Iryanthera juruensis Warb. & $\begin{array}{l}\text { The wood is used in house construction, to make axe } \\
\text { handles and for firewood; the sap is used to treat skin } \\
\text { sores and the illness yunchít. }\end{array}$ \\
\hline
\end{tabular}




\section{Jernigan - Can a Use-based Taxonomy be Natural? An example from Aguaruna folk classification of trees}

\begin{tabular}{|l|l|l|}
\hline $\begin{array}{l}\text { Grouping of } \\
\text { Aguaruna taxa }\end{array}$ & Scientific taxa & Uses \\
\hline GROUP 15 & URTICACEAE & \\
\hline satík & Cecropia membranacea Trécul & $\begin{array}{l}\text { Wood used for firewood; the sap is used to treat hepatitis } \\
\text { and anemia. }\end{array}$ \\
\hline súu & Cecropia engleriana Snethl. & $\begin{array}{l}\text { Wood used for firewood; the sap is used to treat stomach } \\
\text { ache, hepatitis and anemia; leaves and bark used to treat } \\
\text { stingray sting. }\end{array}$ \\
\hline
\end{tabular}


